\title{
Spirit Visionary Leadership in Developing Green School and Character
}

\author{
Nur Kholis ${ }^{1}$, Nuril Mufidah ${ }^{2}$, Lilik Indriharta ${ }^{3}$, Munardji $^{4}$ \\ Institut Agama Islam Negeri Tulungagung, Indonesia ${ }^{1}$ \\ Universitas Islam Negeri Maulana Malik Ibrahim Malang, Indonesia ${ }^{2}$ \\ UPN "Veteran," Yogyakarta, Indonesia ${ }^{3}$ \\ Institut Agama Islam Negeri (IAIN) Tulungagung, Indonesia ${ }^{4}$ \\ $\left\{\underline{\text { fakhryaqil@gmail.com }}{ }^{1}, \underline{\text { nurilmufidah86@uin-malang.ac.id }}{ }^{2}, \underline{\text { lilik@upnyk.ac.id }}{ }^{3}\right.$,
}

\begin{abstract}
Character education strengthening program, and environment-based education or local excellence based education/ green school are new directions for national education targets in Indonesia. In its implementation, it requires the fulfillment of 4 (four) components that are determined, namely school policy, curriculum, participatory based activities, and infrastructure supporting environmental education. The results of the research on the recipient schools show that the principal has a crucial role in achieving this target. The principal's model of approach by finding the values that are fought for and making it energy to form positive habits in all school stakeholders both in the school environment and in the community.
\end{abstract}

Keywords: Character education, Adiwiyata, green school, environment, leadership.

\section{Introduction}

The main topic in this article is knowing, analyzing and categorizing the spirit of developing green schools with character. A green school is a school concept that integrates between religious, social, and school vision values in the overall mindset, attitude pattern, and behavior patterns of all school stakeholders, both at school and outside of school. The school's task is essentially transferring knowledge and skills to be implemented by students in their daily lives to become adults. Adults are characterized by the ability, willingness, and courage to be responsible for the overall attitude and everyday behavior. Adults in students have three, namely; adult, moral adult, and social adult.

The basic concept of green schools in Indonesia is called the Adiwiyata School. There are two criteria for adiwiyata schools, namely; adiwiyata initiation from the government and adiwiyata initiation of the school concerned (adiwiyatamandiri). There are three levels of adiwiyata schools, namely; district, regional and national level adiwiyata. In this article, the concept of adiwiyatais then written as a conversion into a green school concept with character. Environmental awareness and discourse about the Sustainable Development Goals (SDGs) need to be given to students. All elements of education need to carry out what is called Education for Sustainable Development (ESD). Environment-based education or local 
excellence-based education is also being built through the movement of strengthening character education[1].

Adiwiyata is an award given to schools that are considered to have carried out environmental education and realize a caring and intellectual environment in the school environment. Following the government's program, schools in Indonesia have launched programs that can succeed. One exciting program is an effort to obtain the title of Adiwiyataschool; which means the achievement of schools in schools that train character and green school for students. Exposure and analysis of the achievement of targets and standards become interesting to study. This research is essential to get information on planning and implementation of achieving the intended school standard targets.

\section{Literature review}

\subsection{Understanding Green School And Character}

Green school grounds, as a school setting, can contribute to children's physical, mental, social and spiritual well-being[2].Study participants reported that green school grounds are used regularly for teaching some subjects. They also identified a series of barriers that limit the amount of outdoor learning[3]. It can be said that the application of a green school can provide more information and experience to students. The experience is not only cognitive abilities but also the character of students. When a person is said to have character, it usually implies they have distinguishing moral qualities, moral virtues, and moral reasoning abilities[4].

The enthusiasm for developing character green schools began in 2013. This was driven by the desire of all internal school stakeholders to build schools that produce graduates who have an integral character (able to integrate Islamic religious values with social values) in the daily lives of students, at school and outside of school. Such an essential ability, in the view of the principal, will lead to the achievement of the student's personality which is strongly integrated. They will have a high level of knowledge, a healthy attitude, and ethical behavior. All students are expected to have strong characters, namely; have integrative learning, have awareness, the courage to remind themselves and others around them to participate in supporting attitudes of green schools with integrity. The concept of green schools, not only can be understood from the external side, but what is very important is how to integrate knowledge, attitudes, and caring behaviors in all school stakeholders.

One of the critical points for the realization of the target of being a green school is that the school must have a strong character. One proof that schools that have a strong character have special advantages that distinguish them from other schools and make the school special. About Islamic schools, especially at the elementary school level, in 2013 no one had the predicate green shool (sekolahadiwiyata). The public's view of the actual Islamic elementary school at that time was positive. Thisis evidenced by the high interest of the community in registering their sons and daughters at each new student admission each year. This positive view will be strengthened by realizing the green school (Adiwiyata).

To realize a green school with character, several actions are needed, namely; formulate graduate profiles (PL), integrate green school values into the relevant curriculum, and realize them in learning in several subjects. In expressing graduate profiles (PL) formulated based on several things; that is from the wishes, hopes, and mandates conveyed by school stakeholders. Furthermore, the PL was developed into the school's vision and was realized in the mission, program and school activities. School activities are divided into two categories, namely; 
formal and informal activities; curricular and extra-curricular activities; formal curriculum and non-formal curriculum (hidden curriculum). Both models of this activity are expected to strengthen efforts to achieve graduates' distinctive characteristics. Formal and non-formal activities constitute a unity that shapes school culture. School culture is a mindset that develops in schools, thought culture develops based on formal and non-formal, curricular and non-curricular activities of the school, both of which have contributed to the development of good school culture.

The achievement of green character schools requires discipline, commitment, awareness, and sincerity to run all the stages of the process towards the independent adiwiyata school. This information is always conveyed and socialized by school leaders to all school stakeholders (internal-external). With the continuous socialization, everyone in the school hopes to understand with the aim and growing sincerity in guarding and implementing green school programs and activities. Adequate human resources support the green school development program (Adiwiyata). All teachers have commitment and awareness to integrate green school values into the subject matter, including getting students to be proactive so that they have unique behaviors and habits following the standard PL school.

The evaluation criteria for adiwiyata schools have similarities with Islamic characters that are characteristic of Islamic schools. Therefore the achievement of adiwiyata schools is also the goal of achieving the expected character of school graduates. For example the attitude of maintaining cleanliness, maintaining the sanctity of the learning place, caring for the clean and green environment, loving plants, and courage to remind the people around them to be cultured to care about the clean and green environment. Some examples that appear in school include when the principal or teacher forgets to put sandals on the shelves (the place of shoes) after washing in the bathroom, with respect one of the students who know this incident immediately reprimands by saying "sorry Ustadz please put sandals on place provided." Likewise, when there is a guest, a police officer who enters the class in shoes, is immediately reminded by one of the students, "sorry, sir, here the rules are that anyone who enters the class must take off his footwear in the place provided." In addition to the readiness of human resources, the school also prepares auxiliary instruments by providing written rules on the walls of each class corner.

\subsection{Implementation of Student Character Development}

Planting character values for all students is done, in addition to integrating knowledge into subjects also done by habituation. Habits of positive character are also carried out outside the classroom as a form of green school teaching; such as familiarizing students to say, behave, and behave well following school standards. Thisis supported by teacher resources and school regulations that have been agreed and written well so that it becomes the habit/culture of all students. One of the courageous habits displayed by students is directly admonishing all who do not follow the rules; with a system "anyone reminded and reminded." Such practices, according to the guardians of students, are carried home, or outside the school, at home, there are helpers, but students are accustomed to getting out of bed themselves then praying in congregation, cleaning the bed, cleaning the room and house. The guardians of students who are members of the class association are also involved and support the programme by giving input, motivation, home control, and testimony. The class association which consists of parents of students is very supportive of school programs. They have the annual program and activity plans, both related to matters that support the learning, interests, and hobbies of students, as well as those related to cleanliness, beauty, and class health. 


\subsection{Efforts To Implement Environmental Education/ Green School}

The school curriculum is developed oriented towards the environment. To make this happen, working groups (pokja)are formed. The Working Group is led by the teacher and consists of students for each class, for example, there are biopori working groups, cleaning working groups, reforestation working groups, and so on. The duties and authorities of each working group are to organize, maintain and supervise. The formation of working groups is a realization of the planting of knowledge that has been taught in the classroom, the purpose of which is so that the school can implement and monitor efficiently. Each working group is assigned according to their duties, functions, and authorities. For example, the task of the biopori working group includes making biopories on the front, side and back of the school. Biopori is made in a pro-environment and straightforward manner that is made of several holes with a diameter of $15 \mathrm{~cm}$ with a depth of 1 meter, then filled with garbage and organic fertilizer to make it easy to rot and many earthworms to facilitate the absorption of rainwater.

Maintaining greening, maintaining cleanliness and chastity are habituations to all elements of the school. Another essential task of the working group is to maintain, maintain and control. All plants need to be maintained, cleanliness and sanctity of places of worship need to be maintained, bathrooms need to be kept clean. Therefore the teacher always gives examples of good habits so that they become the culture of all students and other school stakeholders. All elements of the school can be examples and supervisors apply the standard habits of adiwiyata school characters. One of the adiwiyata assessment criteria is the courage of all school elements to remind each other of good habits in maintaining character according to the values of adiwiyata schools in a polite manner. Every Friday the students conduct a clean environment (ro'an) for one hour after the Dhuha prayer. They maintain flowers and other greenery, clean classes, terraces, schoolyards and places of worship. Every day before returning there are pickets who take turns cleaning their respective classes.

\section{Result and discussion}

Most quality schools have a strong spirit, have a clear vision, and commitment to the goals set. Such schools have a detailed, systematic and well-planned development road map. Knowledge, understanding, and awareness of the vision, mission, and goals of the school make it possible for all stakeholders to be actively involved. Previous research shows that leaders who are strong and understand their school's vision tend to be useful in managing and developing schools. Therefore, energetic and visionary leadership is a necessity in achieving quality schools.

Visioner leadership is a leader who can turn weaknesses into strengths and turn challenges into opportunities. He set which direction to go, trying as much as possible to direct the energy of all members of the organization to achieve organizational goals[5], so that everyone in the organization is willing to voluntarily align the rhythm, volume, and quality of work to achieve organizational goals[6]. The results of previous studies showed that visionary leadership contributed $36.6 \%$ to the professional performance of teachers, managerial skills contributed $39.6 \%$, and the communication climate contributed $18.5 \%[7]$. Realizing visionary leadership requires commitment, understanding, and awareness that can encourage synergistic efforts in achieving effective and efficient organizational goals. Visionary leadership focuses on the 
ultimate goal, and the ability to design stages of the process of achieving goals in a more concrete manner based on the time-bond set before [8]; [9].

Visionary leaders can effectively apply values and enthusiasm on how to become successful leaders, which are related to the process of interaction between leaders, followers, and situations/contexts[10]; [11]. Leadership practices implemented by Islamic primary school principals who won the Adiwiyata award; namely MI Perwanida, Kota Blitar can be analyzed using the theory of servant leadership. Servant leadership holds that leaders have a moral obligation to serve and lead. Besides, visionary leadership can be analyzed by a leadership approach, which is characterized by reliable service and spiritual, moral emphasis [12]; [13]. Some experts view those successful leaders because they see themselves as servants, while at the class level teachers who succeed in seeing themselves as servants of learning [14]. The view of self as a servant is a leadership attitude based on strong spiritual values, an attitude that has a strong desire to be beneficial to others. Such leaders have characteristics; guided servants, organizations, are seen as human communities, leading from the front, guiding, guiding, protecting and sacrificing, always striving for good for others and putting aside their interests, delegating, caring [15].

The leadership phenomenon of developing green schools and character reflects leadership patterns with a spiritual approach, namely comprehensive leadership that combines various approaches as well as the driving force of leadership. Spiritual leadership is a combination of ethical, ascetic, and mystical leadership [16]; [17]. In practice, this leadership approach prioritizes faith and conscience, cleanses the heart, gives service, enlightens and calms the soul based on a spirit of gratitude and love. Programs developed based on the vision of creating green schools with character. Green character school is a school development that respects, realizes and realizes the surrounding natural and social environment as a basis for learning, to foster fundamental knowledge, attitudes, and skills and produce profiles of graduates with integrity. The form of integrity personality is the perceived compatibility between the values adopted and enforced, and the leadership factor has an essential role in maintaining and developing the culture in question [18]; [19]. Integrity behavior contains elements of open, honest, tolerant, confident, caring, commitment to good traditions. Such behavior deserves to be a role model, a model for all school stakeholders [20].

The integrity attitude that was successfully developed by the school was not only for teachers, guardians of the students/class associations but also for all students. For example, the courage of students reminds politely to the clerics and guests who enter the school who do not heed the culture and school rules. Besides, principals have succeeded in developing an effective school culture in achieving the goal of green schools with character, for example, the involvement of parents/class associations in developing academic potential and potential nonacademic students (interests and hobbies), as well as developing a clean, healthy and green. Effective schools are schools that carry out their functions to the fullest, can adapt to changes in the internal-external world both in the short, medium and long term, and can achieve educational goals as expected beforehand [21]. The development of active school culture, according to several previous studies, was influenced by actual leadership behavior of principals. Useful leadership characteristics are characterized, including; vision is bright, vibrant and courageous, democratic, with integrity, inspiring, long-term oriented, maintaining a balance and harmony between the purpose of the school and the individual goals of the school's citizens, protecting. Effective leadership is the right combination of leadership, management,and entrepreneurship skills in the right place and at the right time to achieve the goals of established institutions and to motivate and continue to develop potential stakeholders [8]; [22]. The success of developing an effective school culture is the necessary capital in 
achieving green school goals that characterize effective by involving school stakeholders as widely as possible.

All elements of school stakeholders; principals, deputy principals, teachers, school committees, class associations, and students are actively involved, hand in hand, help, and develop equal togetherness in achieving the goals of the institution [23]. The objectives of the institution are elaborated into three levels, namely; the primary purpose and purpose of the intermediary. Each school stakeholder has social and academic goals that can support each other for the growing spirit of participation in achieving school goals [24]. For example, parents who have a goal to succeed in academic and non-academic children have strong motivation in every activity and school program. They are willing to contribute to support for basketball training programs, volleyball and even some who are willing to provide extra lessons outside of school hours. The primary purpose of the institution is the growth and development of green school culture and character in all elements of school stakeholders.

Meanwhile, the aim of the intermediary is the involvement of all elements of the school stakeholders in every aspect and stage of achievement of green schools and character. The involvement of all school stakeholders contributes to the success of achieving green schools and character. Some values are fought for and expected to be achieved so that the involvement of all stakeholders is to achieve school goals. The research conducted by [10] shows that values of love, discipline, intelligence, courage, and honesty are the values that underlie the spirit of active school development. Therefore, the results of the Suharsimi study corroborate the findings of this study that based on the findings in this research, the prisoner's leadership has a vital role in the efforts to develop green school culture and character.

The beginning of the development of green school culture (adiwiyata) leadership success requires the principal's patience, dedication, and gentleness, managing first impressions, harmonizing expectations, recognizing stress, managing feedback, building relationships, and using structured methods for leadership development [25]; [26]. In developing such a culture then the principal uses a delegative approach and entrusts all elements of school stakeholders to play an active role in the process of achieving school goals. Such leadership as previous research shows that the influence of delegative-participatory leadership and consultativeadvisors, on the successful implementation of process innovation, each of these leadership behaviors has certain advantages and risks. Therefore both patterns can be applied to complement each other [27]. Delegations made by the principal encourage all stakeholders to mobilize all potential individuals and groups. For example from the teacher elements, they are willing to make an integrative learning plan with values, habituation, and behavior in the learning process. The class association is willing to devote time, energy and finance to the success of green schools and the development of student interest in talent. Students are willing to develop their knowledge, get used to behaving and behaving well and support the process of achieving the goal of a green school with character. Such conditions are relevant to curriculum leadership research, conducted by [28]; [29] that elementary school principals carry out leadership learning through informal communication to improve teacher performance. The principals create a productive and cognitive climate informally to create an atmosphere that supports student learning success. The expanded leadership role can further develop teacher professionalism, loyalty, develop experience while simultaneously supporting teacher knowledge during the period of learning innovation and school management [30].

\section{References}

[1] Kementerian Pendidikan dan Kebudayaan, "Wujudkan Kesadaran Lingkungan 
Melalui Penguatan Pendidikan Karakter," Kementerian Pendidikan dan Kebudayaan, 2016.

[2] J. E. Dyment, "Grounds for health: the intersection of green school grounds and health - promoting schools," Environ. Educ. Res., vol. 14, no. 1, pp. 77-90, 2008.

[3] J. E. Dyment, "Green School Grounds as Sites for Outdoor Learning: Barriers and Opportunities," Int. Res. Geogr. Environ. Educ., vol. 14, no. 1, pp. 28-45, 2005.

[4] N. Park, "Character Strengths and Positive Youth Development," Ann. Am. Acad. Pol. Soc. Sci., vol. 591, no. 1, pp. 40-54, Jan. 2004.

[5] J. P. Kotter, "Seizing opportunities and dodging threats with a dual operating system," Strateg. Leadersh., vol. 42, no. 6, pp. 10-12, Nov. 2014.

[6] J. P. Kotter, Leading Change, With a New Preface by the Author. Boston: Harvard Business Review Press, 2012.

[7] A. Mappaenre, "Kepemimpinan Visioner Kepala Sekolah, Kepemimpinan Diri Guru Dan Sekolah Efektif," JIANA (Jurnal Ilmu Adm. Negara), 2014.

[8] S. Imboden, "Effective Leadership," in Food Safety Management, Elsevier, 2014, pp. 959-973.

[9] J. Blase and J. Blase, "Effective instructional leadership," J. Educ. Adm., vol. 38, no. 2, pp. 130-141, May 2000.

[10] M. Widiyastuti and S. Arikunto, "Dinamika Kepemimpinan Kepala Sekolah Dalam Mengembangkan Sekolah Efektif Di Sd Kanisius Kadirojo, Sengkan, Duwet," J. Akuntabilitas Manaj. Pendidik., vol. 3, no. 1, pp. 82-96, Oct. 2015.

[11] A. Ikhwan, "Manajemen pengembangan kurikulum Keaswajaan dan Kemuhammadiyahan dalam Pembentukan karakter: Studi Multikasus di Sekolah Tinggi Agama Islam Diponegoro dan Sekolah Tinggi Agama Islam Muhammadiyah Tulungagung," Universitas Islam Negeri Maulana Malik Ibrahim Malang, 2016.

[12] S. Sendjaya and J. C. Sarros, "Servant Leadership: Its Origin, Development, and Application in Organizations," J. Leadersh. Organ. Stud., vol. 9, no. 2, pp. 57-64, Sep. 2002.

[13] R. F. Russell, "The role of values in servant leadership," Leadersh. Organ. Dev. J., vol. 22, no. 2, pp. 76-84, Mar. 2001.

[14] R. F. Bowman, "Teacher as Servant Leader," Clear. House A J. Educ. Strateg. Issues Ideas, vol. 78, no. 6, pp. 257-260, Jul. 2005.

[15] L. C. Spears, "Character and Servant Leadership: Ten Characteristics of Effective, Caring Leaders," J. Virtues Leadersh., vol. 1, no. 1, pp. 25-30, 2010.

[16] U. Karimah, "Manajemen dan Kepemimpinan Pendidikan Islam," Al-Murabbi J. Stud. Kependidikan dan Keislam., vol. 2, no. 1, pp. 88-110, 2015.

[17] M. Walid, "Kepemimpinan Spritual Kharismatik (Telaah Kritis Terhadap Kepemimpinan KH. Achmad Muzakki Syah Pengasuh Pondok Pesantren Al-Qodiri)," J. Falasifa, vol. 2, no. 2, 2011.

[18] T. L. Simons, "Behavioral integrity as a critical ingredient for transformational leadership," J. Organ. Chang. Manag., vol. 12, no. 2, pp. 89-104, Apr. 1999.

[19] T. Simons, "Behavioral Integrity: The Perceived Alignment Between Managers' Words and Deeds as a Research Focus," Organ. Sci., vol. 13, no. 1, pp. 18-35, Feb. 2002.

[20] A. L. Davis and H. R. Rothstein, "The Effects of the Perceived Behavioral Integrity of Managers on Employee Attitudes: A Meta-analysis," J. Bus. Ethics, vol. 67, no. 4, pp. 407-419, Oct. 2006.

[21] J. Lenkeit, "Effectiveness measures for cross-sectional studies: a comparison of value- 
added models and contextualised attainment models," Sch. Eff. Sch. Improv., vol. 24, no. 1, pp. 1-25, Mar. 2013.

[22] K. Sethuraman and J. Suresh, "Effective Leadership Styles," Int. Bus. Res., vol. 7, no. 9, Aug. 2014.

[23] N. Kholis, Z. Zamroni, and S. Sumarno, "Mutu sekolah dan budaya partisipasi stakeholders (Studi fenomenologi di sekolah konfesional MIN Tegalasri Wlingi Blitar," J. Pembang. Pendidik. Fondasi dan Apl., vol. 2, no. 2, Dec. 2014.

[24] M. V. Covington, "Goal Theory, Motivation, and School Achievement: An Integrative Review," Annu. Rev. Psychol., vol. 51, no. 1, pp. 171-200, Feb. 2000.

[25] K. Schoonover-Shoffner, "Leadership Transitions," J. Christ. Nurs., vol. 33, no. 2, p. 69, 2016.

[26] S. Manderscheid and A. Ardichvili, "A conceptual model for leadership Transition," Perform. Improv. Q., 2008.

[27] D. E. Krause, D. Gebert, and E. Kearney, "Implementing Process Innovations," J. Leadersh. Organ. Stud., vol. 14, no. 1, pp. 16-25, Aug. 2007.

[28] C. Richards, "Curriculum leadership," Educ. 3-13, vol. 23, no. 3, pp. 3-10, Oct. 1995.

[29] R. M. Ylimaki, "Curriculum Leadership in a Conservative Era," Educ. Adm. Q., vol. 48, no. 2, pp. 304-346, Apr. 2012.

[30] M. Taylor, A. Yates, L. H. Meyer, and P. Kinsella, "Teacher professional leadership in support of teacher professional development," Teach. Teach. Educ., vol. 27, no. 1, pp. 85-94, Jan. 2011. 